\title{
Hubungan Social Comparison dengan Gejala Depresi pada Mahasiswa Pengguna Instagram
}

\author{
Salsabila Auliannisa*, Muhammad Ilmi Hatta \\ Indonesia. \\ *sal.auliannisa@gmail.com, muhammadilmihatta@unisba.ac.id
}

Prodi Ilmu Psikologi, Fakultas Psikologi, Universitas Islam Bandung,

\begin{abstract}
College student need to evaluate themselves, this can be through social comparison. Instagram can be a media for social comparison, because there are photo and video posts from other users. Instagram is an image-based platform that allows users to more easily express themselves, so the content is usually aesthetic and optimized. Thus, the social comparisons made on Instagram are different from the comparisons made in real life. On social media such as Instagram, published information is always the best view of oneself rather than the bad things of a person. If social comparison is done negatively, it can lead individuals to feel negative emotions that are in symptoms of depression. Similarly, individuals with depressive symptoms tend to compare themselves when using Instagram, seeing that other people's lives seem better can lead to negative self-evaluation. This study aims to determine the degree of the relationship between social comparisons and depressive symptom in college students using Instagram is. The research method used is correlational method with 112 college students using Instagram as respondents. The measuring instruments used are the Social Comparison Rating Scale and the Beck Depression Inventory-II. The analysis technique used Rank Spearman correlation technique. The results showed that there was a moderate relationship between social comparisons and depressive symptoms with a correlation value of -0.435 and p-value $(\mathrm{Sig})=$.0.000 . The direction of the relationship between variables is negative, meaning that the lower the social comparison score, the higher the score for depression symptoms in college students who use Instagram.
\end{abstract}

Keywords: Social Comparison, Depressive Symptom, Instagram, College Student.

Abstrak. Mahasiswa memiliki kebutuhan untuk mengevaluasi dirinya, hal ini dapat dipenuhi melalui social comparison. Instagram dapat menjadi sarana social comparison, karena terdapat postingan foto dan video dari penggunalain. Instagram adalah platform berbasis gambar yang membuat penggunanya dapat lebih mudah mengekspresikan diri, sehingga konten yang diunggah biasanya bersifat estetika dan dioptimalkan. Sehingga, social comparison yang dilakukan di Instagram berbeda dengan perbandingan yang dilakukan di kehidupan nyata. Pada media sosial seperti Instagram informasi yang dipublikasikan selalu tampilan terbaik diri daripada hal yang buruk dari diri seseorang. Jika social comparison dilakukan secara negatif, dapat mengarahkan individu merasa emosi negatif yang ada dalam gejala depresi. Begitu pula, individu dengan gejala depresi cenderung membandingkan diri mereka sendiri saat menggunakan Instagram, melihat bahwa kehidupan orang lain tampak lebih baik dapat membuat menilai diri sendiri secara negatif. Tujuan penelitian ini adalah untuk mengetahui seberapa erat hubungan antara social comparison dengan gejala depresi pada mahasiswa pengguna Instagram. Metode penelitian yang digunakan adalah korelasional dengan responden 112 orang mahasiswa pengguna Instagram. Alat ukur yang digunakan adalah Social Comparison Rating Scale dan Beck Depression Inventory - II. Teknik analisis penelitian ini menggunakan Rank Spearman. Hasil penelitian menunjukan terdapat hubungan sedang/moderate antara social comparison dengan gejala depresi dengan nilai korelasi sebesar $-0,435$ dan dan p-value (Sig.) $=0,000$. Arah hubungan antar variabel negatif artinya semakin rendah skor social comparison maka semakin tinggi skor gejala depresi pada mahasiswa pengguna Instagram.

Kata Kunci: Social Comparison, Gejala Depresi, Instagram, Mahasiswa. 


\section{A. Pendahuluan}

Seiring kemajuan teknologi, saat ini media sosial menjadi cara tercepat dan termudah untuk berinteraksi serta menyediakan media untuk orang-orang dari berbagai negara, budaya, dan bahasa untuk saling berinteraksi satu sama lain. Pengguna dapat berbagi, bertukar pandang, dan berkomunikasi satu sama lain meskipun ada jarak yang memisahkan mereka (Sawyer, 2011). Kemudahan yang ditawarkan membuat media sosial menjadi populer dan penggunanya meningkat setiap tahunnya. Di Indonesia, pada tahun 2020 terdapat 160 juta pengguna media sosial. Jumlahnya meningkat sebesar 12 juta atau sekitar 8,1\% dibandingkan tahun 2019 . Anak muda berusia 18-24 tahun menjadi pengguna terbanyak kedua media sosial di Indonesia (We Are Social \& Hootsuite, 2020).

Anak muda menjadi pengguna media sosial paling tinggi, hal ini dikarenakan anak muda tumbuh dengan penggunaan media sosial dan menganggapnya sebagai bagian normal dari kehidupan. Hal lainnya, bahwa anak muda berusia 18-24 tahun termasuk pada fase emerging adulthood yaitu tahap kehidupan ketika mereka "self-focused". Media sosial juga menjadi sarana hiburan bagi emerging adulthood dan memungkinkan mereka untuk tetap terhubung dengan orang-orang yang mereka cintai, bahkan jika orang-orang itu berada di sisi lain negara atau dunia (Arnett, 2014).

Salah satu platform media sosial yang populer di kalangan anak muda di Indonesia yaitu Instagram. Berdasarkan survei NapoleonCat.com (2020) anak muda dengan rentang usia 18-24 tahun menjadi pengguna terbanyak Instagram di Indonesia, yaitu sebanyak 30 juta pengguna aktif. Dari jumlah keseluruhan pengguna aktifnya, Instagram memiliki $79 \%$ atau 63 juta pengguna aktif di Indonesia sehingga membuatnya menjadi salah satu media sosial paling banyak digunakan (We Are Social \& Hootsuite, 2020).

Instagram adalah aplikasi untuk membagikan foto dan video yang tersedia di perangkat iOS Apple, Android, dan Windows Phone. Fitur utama Instagram adalah dapat membagikan postingan foto dan video. Foto atau video ini dapat ditingkatkan menggunakan teknologi pemfilteran. Foto dan video ini kemudian diunggah ke profil pengguna kemudian pengikut dapat "menyukai" dan mengomentarinya. Tujuan penggunaan aplikasi adalah untuk membagikan foto atau video yang menyertakan hashtag (\#) sehingga pengguna lain dapat melihat foto yang dibagikan tersebut (Sheldon \& Bryant, 2016).

Konten yang diunggah biasanya bersifat estetika dan dioptimalkan untuk selfpresentation, juga merupakan hasil ekspresi diri yang kreatif (Meier \& Schäfer, 2018). Motif ini terutama didukung oleh fakta bahwa Instagram adalah platform berbasis gambar yang membuat penggunanya dapat lebih mudah menggunakan gambar daripada teks untuk mengekspresikan diri (Lee et al., 2015). Pengguna sering merasa terinspirasi dengan kontenkonten yang ada di Instagram. Misalnya, pengguna terinspirasi untuk bepergian dan terbang jauh saat berlibur setelah melihat konten alam yang menggugah. Didapatkan juga bahwa peningkatan perjalanan menuju tujuan alam yang dulunya terpencil meningkat setelah dipopulerkan di Instagram. Jadi, "Inspirasi Instagram" mungkin bermanfaat bagi penggunanya, juga bermanfaat untuk implikasi ekonomi dan periklanan (Meier et al., 2021).

Instagram memberikan dampak positif bagi penggunanya. Namun, di sisi lain Instagram memiliki dampak negatif bagi penggunanya. Pengguna sering menggunakan Instagram untuk escapism, yaitu pengguna memanfaatkan Instagram sebagai cara untuk melarikan diri dari kehidupan sehari-hari mereka melalui konten orang lain (Lee et al, 2015).

Hal lainnya, pada survei Royal Society for Public Health atau disingkat RSPH (2017), para anak muda diminta untuk menilai bagaimana masing-masing platform media sosial yang mereka gunakan berdampak pada masalah terkait kesehatan mental dan kesejahteraan. Survei ini dilakukan kepada 1.500 anak muda berusia 14 - 24 tahun. Hasil dari survei menyebutkan media sosial Instagram menempati peringkat terburuk untuk kesehatan mental dan well-being, berdasarkan pada dampak negatif yang diukur yaitu kecemasan, depresi, loneliness, kualitas tidur, masalah citra diri, hubungan di dunia nyata, dan fear of missing out (FoMo). Mereka juga menyarankan bahwa anak muda yang merupakan pengguna berat Instagram rentan terhadap tekanan psikologis termasuk kecemasan dan depresi (RSPH, 2017). 
Menurut Beck dan Alford (2009) depresi adalah terjadinya sejumlah perubahan spesifik suasana hati dengan perubahan yang mengarah pada emosi negatif (sadness, loneliness, apathy), timbul konsep diri negatif, timbulnya keinginan untuk menghukum diri sendiri, pengalaman perubahan perilaku fungsi fisik dan tingkat aktivitas, yaitu aktivitas menurun atau meningkat secara tidak normal. Gangguan depresi sering dimulai pada usia anak muda sehingga dapat membuat mengurangi fungsi seseorang dan sering berulang. Untuk alasan ini, depresi menjadi penyebab utama beban kesehatan di seluruh dunia dan perlu adanya perhatian (WHO, 2012). Menurut Beck dan Alford (2009) salah satu penyebab depresi ialah adanya distorsi kognitif. Distorsi kognitif yaitu pandangan negatif tentang diri sendiri, pengalaman dan masa depan. Salah satu bentuk distorsi kognitif adalah perbandingan yang tidak adil antara diri sendiri dengan orang lain. Di sisi lain, media sosial membuka kemungkinan untuk membandingkan diri sendiri dengan orang lain (Aziz, 2020).

Menurut Festinger (dalam sarwono, 2014) social comparison adalah proses interaksi dan perilaku kompetitif dalam interaksi sosial yang disebabkan oleh kebutuhan akan penilaian diri. Kebutuhan menilai diri dapat dipenuhi dengan membandingkan diri dengan orang lain. Media sosial seperti Instagram menyediakan sarana bagi penggunanya untuk membandingkan diri, karena terdapat fitur foto dan video untuk melihat kehidupan orang lain (Gaol et al., 2018). Namun, social comparison yang dilakukan di Instagram berbeda dengan perbandingan yang dilakukan di kehidupan nyata. Pada media sosial seperti Instagram informasi yang dipublikasikan selalu tampilan terbaik diri daripada hal yang buruk dari diri seseorang. Hal ini membuat perbandingan sosial menjadi ke atas atau disebut upwards comparison yang lebih mungkin terjadi (Kross et al., 2013).

Upwards comparison dapat memotivasi, tetapi biasanya mengarah pada perasaan tidak mampu. Oleh karena itu, perbandingan semacam ini disebut juga negative comparison karena menyimpulkan bahwa seseorang merasa lebih negatif (yaitu rendah diri, tidak disukai, kurang menarik, dll) jika dibandingkan dengan orang lain (Gibbons dalam Gaol et al., 2018). Lebih lanjut, anak muda yang melihat teman-temannya sering berlibur atau hangout membuat anak muda merasa ketinggalan sementara teman-temannya menikmati hidup. Perasaan ini dapat meningkatkan sikap comparison dan merasa kalah pada orang muda. Anak muda dapat melihat banyak foto atau video yang diedit di media sosial dan membandingkannya dengan kehidupan mereka yang tampaknya biasa-biasa saja (RSPH, 2017).

Pada penelitian ini, penulis memilih subjek mahasiswa rentang usia 18-24 tahun. Hal ini, dikarenakan rentang usia 18-24 tahun merupakan pengguna instagram terbanyak di Indonesia (NapoleonCat, 2020). Pada rentang usia tersebut, individu memasuki masa emerging adulthood dan pada tahap ini banyak individu sedang melanjutkan studi ke jenjang universitas (Arnett, 2014). Sehingga, dapat diasumsikan bahwa pengguna Instagram di Indonesia banyak yang merupakan mahasiswa. Hal lainnya, karena banyak mahasiswa yang kurang siap menghadapi tantangan akademik dan sosial yang disediakan oleh lingkungan perguruan tinggi, mahasiswa mengandalkan teman mahasiswa yang lain untuk evaluasi tentang kemampuannya sendiri untuk berhasil. Artinya, ketekunan mahasiswa di perguruan tinggi sebagian disebabkan oleh evaluasi mereka terhadap kemampuan, perilaku, dan keterampilan mereka relatif terhadap mahasiswa yang lain (Saeed \& Sonnentag, 2018). Ketika mahasiswa mengevaluasi diri mereka sendiri relatif terhadap mahasiswa lainnya, mereka terlibat dalam social comparison (Festinger, 1954).

Penelitian ini dilakukan di Bandung dengan memperhitungkan, pada penelitian Syachfira dan Nawangsih (2020) di kota Bandung, didapatkan bahwa pada penelitian tersebut mayoritas mahasiswa pengguna Instagram di Kota Bandung memiliki social comparison yang tinggi yaitu sebesar $65,75 \%$ mahasiswa. Bila dibandingkan dengan penelitian yang dilakukan di Kota Malang oleh Chusniah et al., (2021) didapatkan bahwa mayoritas mahasiswa pengguna Instagram memiliki social comparison yang rendah yaitu sebesar 56.60\%.

Berdasarkan latar belakang yang telah diuraikan, maka perumusan masalah dalam penelitian ini sebagai berikut:

1. Bagaimana gambaran social comparison pada mahasiswa pengguna Instagram?

2. Bagaimana gambaran gejala depresi pada mahasiswa pengguna Instagram? 
3. Seberapa erat hubungan antara social comparison dengan gejala depresi pada mahasiswa pengguna Instagram?

\section{B. Metodologi Penelitian}

Penelitian ini menggunakan pendekatan kuantitatif dan metode penelitian yang digunakan adalah korelasional. Metode penelitian korelasional digunakan bertujuan untuk mengetahui derajat keeratan hubungan antara dua variabel dengan menggunakan data statistik. Penelitian korelasional tidak menjelaskan pola sebab akibat (silalahi, 2019).

Alat ukur yang digunakan untuk variabel Social Comparison adalah Social Comparison Rating Scale (Allan \& Gilbert, 1995) diadaptasi ke Bahasa Indonesia oleh Gaol et al (2018). Skala ini terdiri dari 11 item, pada setiap item subjek memilih angka dari 1 hingga 10 yang paling menggambarkan perasaan mereka saat membandingkan diri dengan orang lain di Instagram yaitu diantara dua pilihan (misalnya, inferior / superior, tidak kompeten / lebih kompeten, dll). Skor total yang mungkin dapat berkisar dari 11 hingga 110. Skor yang lebih tinggi menunjukkan social comparison pada kategori positif.

Alat ukur yang digunakan untuk variabel gejala depresi adalah Beck Depression Inventory-II oleh Aaron T Beck yang diadaptasi ke Bahasa Indonesia oleh Maulida (2012). Beck Depression Inventory-II dirancang untuk mengukur gejala dan tingkat keparahan depresi pada orang berusia 13 tahun. BDI-II terdiri dari 21 item. Skor total paling rendah ialah 0 , sedangkan yang paling tinggi ialah 63 .

\section{Hasil Penelitian dan Pembahasan}

\section{Hubungan Antara Social Comparison dengan Gejala Depresi}

Berikut adalah hasil penelitian mengenai hubungan antara social comparison dengan gejala depresi, yang diuji menggunakan teknik analisis korelasi Rank Spearman. Hasil pengujian dijelaskan pada tabel 1.

Tabel 1. Uji Korelasi Social Comparison dengan Gejala Depresi

\begin{tabular}{|c|c|c|c|}
\hline \multicolumn{2}{|c|}{} & $\begin{array}{c}\text { Social } \\
\text { Comparison }\end{array}$ & Gejala Depresi \\
\hline \multirow{2}{*}{$\begin{array}{c}\text { Social } \\
\text { comparison }\end{array}$} & $\begin{array}{c}\text { Correlation } \\
\text { Coefficient } \\
\text { Sig. (2-tailed) }\end{array}$ & 1.000 & $-.435^{* *}$ \\
\cline { 3 - 4 } & Correlation & $-.435^{* *}$ & .000 \\
\hline $\begin{array}{c}\text { Gejala } \\
\text { Depresi }\end{array}$ & $\begin{array}{c}\text { Coefficient } \\
\text { Sig. (2-tailed) }\end{array}$ & .000 & 1.000 \\
\cline { 3 - 4 } & \multicolumn{2}{|c|}{} \\
\hline **. Correlation is significant at the 0.01 level (2-tailed).
\end{tabular}

Dari tabel di atas, dapat diketahui bahwa besarnya hubungan antara social comparison dengan gejala depresi adalah -0.435 . Hubungan ini termasuk kategori moderat/sedang menurut tabel kriteria Guilford (Silalahi, 2019). Terdapat hubungan negatif antara social comparison dengan gejala derpesi. Artinya semakin rendah skor social comparison maka semakin tinggi skor gejala depresi pada mahasiswa pengguna Instagram.

Hasil penelitian ini sejalan dengan penelitian yang dilakukan oleh Gaol et al (2018) bahwa terdapat hubungan yang negatif antara social comparison dengan gejala depresi pada anak muda pengguna Instagram. Maksudnya, semakin orang merasa negatif dibandingkan dengan orang lain di Instagram, semakin banyak gejala depresi yang mereka rasakan. 


\section{Gambaran Social Comparison dan Gejala Depresi Pada Responden}

Tabel 2. Kategori Social Comparison

\begin{tabular}{|c|c|c|}
\hline Kategori & Frekuensi & Presentase \\
\hline Positif & 50 & $44.6 \%$ \\
\hline Negatif & 62 & $55.4 \%$ \\
\hline Total & 112 & $100 \%$ \\
\hline
\end{tabular}

Berdasarkan tabel 2 dapat diketahui bahwa sebanyak 50 responden $(44,6 \%)$ memiliki social comparison pada kategori positif dan 62 responden lainnya memiliki social comparison pada kategori negatif $(55,4 \%)$. Sehingga, dapat disimpulkan bahwa responden penelitian ini didominasi oleh responden yang membandingkan diri secara negatif.

Mahasiswa yang memiliki social comparison negatif atau membandingkan diri secara negatif di Instagram dapat mungkin terjadi. Hal ini dijelaskan dalam penelitian Hwnag (2019) ketika pengguna Instagram melihat foto orang lain, dan merasa bahwa orang lain memiliki kehidupan yang lebih baik daripada mereka atau orang lain melakukan lebih baik daripada mereka, perbandingan sosial tersebut meningkatkan perasaan tertekan atau rendah diri yang memicu menilai diri lebih buruk dibanding penggunalain.

Tabel 3. Kategori Derajat Gejala Depresi

\begin{tabular}{|c|c|c|}
\hline Kategori & Frekuensi & Presentase \\
\hline Minimal & 14 & $12,5 \%$ \\
\hline Ringan & 22 & $19,6 \%$ \\
\hline Sedang & 58 & $51,8 \%$ \\
\hline Berat & 18 & $16,1 \%$ \\
\hline Total & 112 & $100 \%$ \\
\hline
\end{tabular}

Berdasarkan tabel 3, diketahui bahwa sebanyak 14 responden mengalami gejala depresi minimal (12,5\%), 22 responden mengalami gejala depresi ringan (19,6\%), 58 responden mengalami gejala depresi sedang $(51,8 \%)$, dan 18 responden mengalami gejala depresi berat $(16,1 \%)$. Sehingga, dapat disimpulkan bahwa responden penelitian didominasi oleh responden yang mengalami gejala depresi sedang/Moderate.

Pada seseorang yang mengalami gejala depresi pada aspek gejala kognitif, Mereka lebih sering melakukan social comparison dengan orang lain daripada tidak, dan menyimpulkan bahwa mereka lebih rendah (Beck \& Alford, 2009). Artinya mahasiswa yang memiliki gejala depresi pada saat menggunakan Instagram memungkinkan sering membandingkan diri dengan pengguna lain dan dapat mengevaluasi diri secara negatif (memandang rendah dirinya) sehingga dapat memperparah gejala depresi yang dirasakan.

Hal yang mesti diperhatikan bahwa media sosial seperti Instagram yang berorientasi pada citra/kesan mendorong penyajian konten hanya karakterisasi yang paling positif dan terbaik dari kehidupan seseorang (Lup et al., 2015). Dengan demikian, Instagram menyajikan informasi yang ideal dan kesan yang baik pada diri seseorang. Pengguna membandingkan diri mereka yang sebenarnya dengan versi online yang ideal sehingga membuat upwards comparison atau membandingkan diri dengan orang yang dianggap lebih superior, lebih menonjol di media sosial seperti Instagram daripada offline (Appel et al., 2016). Mengacu pada teori Festinger (dalam Sarwono, 2014) pada kesimpulan 3 B menyebutkan bila hanya tersedia objek pembanding yang jauh berbeda maka evaluasi terkait opini dan kemampuannya menjadi tidak tepat. 


\section{Kesimpulan}

Berdasarkan hasil penelitian yang dilakukan mengenai hubungan social comparison dengan gejala depresi pada mahasiswa pengguna Instagram, dapat disimpulkan bahwa:

1. Mayoritas mahasiswa dalam penelitin ini memiliki social comparison pada kategori negatif.

2. Mayoritas mahasiswa dalam penelitian ini mengalami gejala depresi pada tingkat sedang/moderate.

3. Terdapat hubungan sedang/moderate yang signifikan antara social comparison dengan gejala depresi pada mahasiswa pengguna Instagram, didapatkan nilai korelasi sebesar $-0,435$. Arah hubungannya negatif artinya semakin rendah skor social comparison maka semakin tinggi skor gejala depresi pada mahasiswa pengguna Instagram.

\section{Acknowledge}

Terimakasih kepada Dr. M. Ilmi Hatta, Dra, M.Psi, Psikolog selaku pembimbing yang telah memberikan ilmu, arahan sehingga penulis dapat menyusun dan menyelesaikan penelitan ini. Terimakasih kepada para responden penelitian yang telah bersedia meluangkan waktunya untuk berpartisipasi dalam pengambilan data.

\section{Daftar Pustaka}

[1] Allan, S., \& Gilbert, P. (1995). A social comparison scale: Psychometric properties and relationship to psychopathology. Personality and Individual Differences. https://doi.org/10.1016/0191-8869(95)00086-L

[2] Appel, H., Gerlach, A. L., \& Crusius, J. (2016). The interplay between Facebook use, social comparison, envy, and depression. In Current Opinion in Psychology. https://doi.org/10.1016/j.copsyc.2015.10.006

[3] Arnett, J. J. (2014). Emerging Adulthood: The Winding Road from the Late Teens through the Twenties. In Emerging Adulthood: The Winding Road from the Late Teens through the Twenties. https://doi.org/10.1093/acprof:oso/9780195309379.001.0001

[4] Aziz, A. A. Al. (2020). Hubungan antara intensitas penggunaan media sosial dan tingkat depresi pada mahasiswa. Acta Psychologia.

[5] Beck, A. T., \& Alford, B. A. (2009). Depression Causes and Treatment, second edition. In University of Pennsylvania Press. https://doi.org/10.4324/9781315824338

[6] Chusniah, T., Wildyarti, R. Y., Danyalin, A. M., \& Shodiq, A. (2021). Social Comparison as a Predictor of Self-Esteem Amongst Instagram-Using Students during the Covid-19 Pandemic. KnE Social Sciences. https://doi.org/10.18502/kss.v4i15.8203

[7] Festinger, L. (1954). A Theory of Social Comparison Processes. Human Relations. https://doi.org/10.1177/001872675400700202

[8] Gaol, L. A. L., Mutiara, A. B., Saraswati, N. L., Rahmadini, R., \& Hilmah, M. A. (2018). The relationship between social comparison and depressive symptoms among Indonesian Instagram users. https://doi.org/10.2991/uipsur-17.2018.19

[9] Hwnag, H. S. (2019). Why social comparison on instagram matters: Its impact on depression. KSII Transactions on Internet and Information Systems. https://doi.org/10.3837/tiis.2019.03.029

[10] Kross, E., Verduyn, P., Demiralp, E., Park, J., Lee, D. S., Lin, N., Shablack, H., Jonides, J., \& Ybarra, O. (2013). Facebook use predicts declines in subjective well-being in young adults. In Forschende Komplementarmedizin.

[11] Lee, E., Lee, J. A., Moon, J. H., \& Sung, Y. (2015). Pictures Speak Louder than Words: Motivations for Using Instagram. Cyberpsychology, Behavior, and Social Networking. https://doi.org/10.1089/cyber.2015.0157

[12] Lup, K., Trub, L., \& Rosenthal, L. (2015). Instagram \#Instasad?: Exploring Associations Among Instagram Use, Depressive Symptoms, Negative Social Comparison, and Strangers Followed. Cyberpsychology, Behavior, and Social 
Networking. https://doi.org/10.1089/cyber.2014.0560

[13] Marcus, M., Yasamy, M. T., van Ommeren, M., \& Chisholm, D. (2012). Depression, a global public health concern. WHO Department of Mental Health and Substance Abuse.

[14] Maulida, A. (2012). Gambaran Tingkat Depresi Pada Mahasiswa Program Sarjana Yang Melakukan Konseling Di Badan Konseling Mahasiswa Universitas Indonesia. Universitas Indonesia.

[15] Meier, A., Gilbert, A., Börner, S., \& Possler, D. (2021). Instagram inspiration: How upward comparison on social network sites can contribute to well-being. Journal of Communication. https://doi.org/10.1093/JOC/JQAA025

[16] Meier, A., \& Schäfer, S. (2018). Positive Side of Social Comparison on Social Network Sites: How Envy Can Drive Inspiration on Instagram. Cyberpsychology, Behavior, and Social Networking. https://doi.org/10.1089/cyber.2017.0708

[17] NapoleonCat. (2021). Instagram Users in Indonesia November 2020. In Www.Napoleoncat.Com.

[18] RSPH. (2017). Instagram ranked worst for young people's mental health. 19 Mayo.

[19] Saeed, Z., \& Sonnentag, T. L. (2018). Role of Self-Compassion on College Students' Social Self-Evaluations and Affect Across Two Domains. Psi Chi Journal of Psychological Research. https://doi.org/10.24839/2325-7342.jn23.2.132

[20] Sarwono, S. W. (2014). Teori-Teori Psikologi Sosial. In PT. Rajagrafindo Persada.

[21] Sawyer, R. (2011). The Impact of New Social Media on Intercultural Adaptation. Digital Commons.

[22] Sheldon, P., \& Bryant, K. (2016). Instagram: Motives for its use and relationship to narcissism and contextual age. Computers in Human Behavior. https://doi.org/10.1016/j.chb.2015.12.059

[23] Silalahi, U. (2019). Metode Penelitian Sosial Kuantitatif. Pt. Refika Aditama.

[24] Syachfira, N., \& Nawangsih, E. (2020). Hubungan social comparison dan self-esteem pada mahasiswa pengguna instagram. Prosiding Psikologi.

[25] We Are Social \& Hootsuite. (2020). Indonesia Digital report 2020. Global Digital Insights. 